\title{
Synthesis of an efficient hydroxyapatite-chitosan-montmorillonite thin film for the adsorption of anionic and cationic dyes: adsorption isotherm, kinetic and thermodynamic study
}

\author{
M. Joudi • H. Nasserlah ${ }^{1}$ · H. Hafdi ${ }^{1}$ J. Mouldar ${ }^{1}$ - B. Hatimi ${ }^{1}$ - M. A. El Mhammedi ${ }^{2}$ M. Bakasse ${ }^{1}$
}

Received: 28 February 2020 / Accepted: 28 April 2020 / Published online: 15 May 2020

(c) Springer Nature Switzerland AG 2020

\begin{abstract}
Adsorption of indigo carmine (IC), methyl orange (MO) and methylene blue (MB) onto hydroxyapatite-chitosan-montmorillonite (HAP-CTS-Mt) film was studied. The influence of contact time, solution $\mathrm{pH}$, initial dyes concentration, amount of HAP-CTS-Mt film and solution temperature were scrutinized. Characteristic bands and structure of HAP-CTS-Mt film were determined using Fourier infrared spectroscopy and X-ray diffraction. The optimal concentrations of IC, MO, and MB were $20 \mathrm{mg} / \mathrm{L}, 50 \mathrm{mg} / \mathrm{L}$, and $20 \mathrm{mg} / \mathrm{L}$, respectively. Optimal dose of HAP-CTS-Mt was $0.2 \mathrm{~g} / \mathrm{L}$ for IC and MB and $0.5 \mathrm{~g} / \mathrm{L}$ for MO. The adsorption process of IC, MO, and MB using HAP-CTS-Mt film was verified by Langmuir isotherm model with maximum adsorption capacities of $243.18 \mathrm{mg} / \mathrm{g}, 137.5 \mathrm{mg} / \mathrm{g}$ and $168.52 \mathrm{mg} / \mathrm{g}$ for IC, MO, and MB, respectively. The adsorption kinetics of IC, MO, and MB onto HAP-CTS-Mt film were well fitted by the pseudo-second-order model. The HAP-CTS-Mt thin film can be employed as an efficient adsorbent for removal of IC, MO, and MB dyes from aqueous solutions.
\end{abstract}

Keywords Adsorption · Hydroxyapatite-chitosan-montmorillonite film · Anionic dye · Cationic dye · Adsorption kinetics · Adsorption isotherms

\section{Introduction}

Recently, the treatment of industrial wastewater, particularly in textile and chemical industries has been getting increasing attention [1-4]. A very small amount of dye in water is highly visible and toxic to aquatic life; dye effluents do not only distress the aquatic system, it also inhibits the transmittance of light into water which harms the ecosystem [5-8]. Therefore, the removal of dyes using different processes became a fundamental concern for the environment.

Several techniques have been applied to manage dyes effluents [9]. Adsorption processes remain the preferred technique for the decontamination of effluents from textile and dyeing industries [10-15]due to its simplicity and cost-effectiveness compared to other methods (coagulation and flocculation [16], ozonation [17], membrane [12], electrochemical [18, 19], fungal discoloration [20].

Chitosan (CTS) has been employed as an adsorbent in wastewater treatment in many studies [21,22]. However, it has some limits regarding its solubility only attained in acidic medium. Many researchers have focused on adding inorganic materials to CTS, for example; calcium phosphates, hydroxyapatite (HAP) and montmorillonite (Mt) clay, the alteration of their structure can successfully improve their adsorption capabilities [23-27].

In this study, a mixture of HAP, CTS, and Mt was developed in the form of a thin film; he role of HAP in the

\footnotetext{
$\triangle$ M. Bakasse, minabakasse@yahoo.fr | ${ }^{1}$ Laboratory of Chemistry Organic, Bioorganic and Environment, Faculty of Science, University Chouaib Doukkali, 24000 El Jadida, Morocco. ${ }^{2}$ Laboratory of Chemistry and Mathematical Modeling, Faculty Polydisciplinaire, University Hassan 1er Khouribga, Khouribga, Morocco.
} 
HAP-CTS-Mt thin film was to stabilize CTS and provide adsorption sites by first adsorbing $\mathrm{Ca}^{2+}$ through the amino. Groups on the surface of the CTS and then by slowly reacting with $\mathrm{PO}_{4}{ }^{3-}$ ions [28]. It was further tested for the adsorption of $\mathrm{IC}, \mathrm{MO}$, and $\mathrm{MB}$ and the effects of solution $\mathrm{pH}$, temperature, dose of adsorbent and initial IC, MB, and MO concentrations were studied.

\section{Materials and methods}

\subsection{Materials}

Indigo Carmine dye (IC), chemical formula: $\mathrm{C}_{16} \mathrm{H}_{8} \mathrm{O}_{8} \mathrm{~N}_{2} \mathrm{~S}_{2} \mathrm{Na}_{2}$, FW: $466.36 \mathrm{~g} / \mathrm{mol}, \lambda_{\max }=610 \mathrm{~nm}$ was supplied by Rrolab. Methyl Orange dye (MO), chemical formula: $\mathrm{C}_{14} \mathrm{H}_{14} \mathrm{~N}_{3} \mathrm{NaO}_{3} \mathrm{~S}$, FW: $327.33 \mathrm{~g} / \mathrm{mol}, \lambda_{\max }=464 \mathrm{~nm}$ was supplied by Sigma Aldrich. The chemical formula of Methylene Blue (MB) is $\mathrm{C}_{16} \mathrm{H}_{18} \mathrm{CIN}_{3} \mathrm{~S}$, FW: $319.85 \mathrm{~g} / \mathrm{mol}$, $\lambda_{\max }=670 \mathrm{~nm}$ and was obtained from Sigma Aldrich. The Molecular formula of the chitosan used in this study is $\mathrm{C}_{12} \mathrm{H}_{24} \mathrm{~N}_{2} \mathrm{O}_{9}$, FW: $100 \mathrm{KDa}$, (CTS, $>85 \%$ deacetylation) it was purchased from Sigma Aldrich. The montmorillonite $\mathrm{Na}^{+}(\mathrm{Mt})$ was procured from Southern Clay Products, Inc. The composition of sodium montmorillonite particles is as follows (wt\%): $\mathrm{Na}_{2} \mathrm{O}: 7.223, \mathrm{MgO}: 4.133, \mathrm{Al}_{2} \mathrm{O}_{3}: 19.986$, $\mathrm{SiO}_{2}: 56.851, \mathrm{P}_{2} \mathrm{O}_{5}: 0.022, \mathrm{~K}_{2} \mathrm{O}: 0.442, \mathrm{CaO}: 0.698, \mathrm{Mno} .0 .053$, TiO:0.368, $\mathrm{Fe}_{2} \mathrm{O}_{3}: 7.936$. Hydroxyapatite (HAP) $\mathrm{Ca}_{10}\left(\mathrm{PO}_{4}\right)_{6}$ $(\mathrm{OH})_{2}$ was synthesized from Moroccan phosphogypsum waste in our previous published study [29], this method leads to obtaining HAP with a $(\mathrm{Ca} / \mathrm{P})=1.667$ and with a high purity, its chemical compositions(wt\%): Ca 33.45, P: 15.51, Na: 0.13, C: 0.21 and F 0.03. Mt, HAP, CTS and HAP-CTS-Mt thin film were characterized by $X$-ray diffraction using a diffractometer (XRD: BRUKER), $C u$ Ka radiation $(\lambda=1.54 \AA)$ created at $40 \mathrm{kV}$, a scan range $2 \theta$ equal to $3-70^{\circ}$. These samples were also analyzed using an FT-IR spectrometer (Alpha Burker) ranging from 373 to $4000 \mathrm{~cm}^{-1}$.

\subsection{Synthesis of HAP-CTS-Mt thin film}

An initial chitosan solution was obtained by dissolving $3.5 \mathrm{~g}$ of chitosan in $0.1 \mathrm{~L}$ of a $0.1 \mathrm{M}$ acetic acid solution. The dissolution was performed for $3 \mathrm{~h}$ with continuous stirring at room temperature. CTS-HAP suspension was formed by adding $0.4375 \mathrm{~g} \mathrm{HAP}$ to CTS solution; the mixture was stirred for $24 \mathrm{~h} .0 .4375 \mathrm{~g}$ of Mt was dissolved separately in $30 \mathrm{~mL}$ deionized water and was stirred mechanically for $24 \mathrm{~h}$. Both CTS-HAP and Mt solutions were mixed together thoroughly to form a gel, then spread out evenly on a glass surface and was left to dry in open air to form thin sheets.

\subsection{Adsorption experiments}

Batch adsorption study of IC, MO, and MB on HAP-CTS-Mt was conducted to investigate the effect of various operating parameters, including contact time (0-150 $\mathrm{min})$, adsorbent dose $(0-1 \mathrm{~g} / \mathrm{L})$, solution $\mathrm{pH}(4-10)$, initial IC, MO and $\mathrm{MB}$ concentrations $(0-200 \mathrm{mg} / \mathrm{L})$ and solution temperature (293-333 K). A specific amount of HAP-CTS-Mt was added in $100 \mathrm{ml}$ of dye aqueous solution. The $\mathrm{pH}$ was adjusted using a few drops of $0.1 \mathrm{M} \mathrm{HCl}$ or $0.1 \mathrm{M} \mathrm{NaOH}$. The adsorbed amounts of $\mathrm{IC}, \mathrm{MO}$, and $\mathrm{MB}$ were determined using Jasco V-630 UV visible spectrophotometer by measuring the absorbance at $610 \mathrm{~nm}, 464 \mathrm{~nm}$, and $670 \mathrm{~nm}$ of $I C, M O$, and $M B$, respectively. The removal percentage of IC, MO, and MB onto HAP-CTS-Mt and the adsorption capacity at equilibrium $\left(\mathrm{q}_{\mathrm{e}}\right)$ and at time $\left(\mathrm{q}_{\mathrm{t}}\right)(\mathrm{mg} / \mathrm{g})$ was determined by the following equations:

$\%$ Removal $=\frac{C_{0}-C_{e}}{C_{0}} \times 100$

$\mathrm{q}_{\mathrm{e}}=\frac{\mathrm{C}_{0}-\mathrm{C}_{\mathrm{e}}}{\mathrm{M}} \times \mathrm{V}$

$\mathrm{q}_{\mathrm{t}}=\frac{\mathrm{C}_{0}-\mathrm{C}_{\mathrm{t}}}{\mathrm{m}} \times \mathrm{V}$

where $C_{0}(\mathrm{mg} / \mathrm{L})$ is the initial IC, MO and MB concentrations, $C_{t}$ and $C_{e}$ are the dye concentrations at time (t) and at equilibrium, $\mathrm{m}(\mathrm{g})$ is the amount of HAP-CTS-Mt and V $(\mathrm{L})$ is the volume of the solution [30].

\section{Results and discussion}

\subsection{Adsorbent characterization by XRD and FTIR}

The XRD of CTS, Mt, HAP and HAP-CTS-Mt are presented in Fig. 1a. CTS powder diffractogram showed a peak at $2 \theta=9.8^{\circ}$ assigned to (020) and another one at $2 \theta=19.9^{\circ}$ which was attributed to $(110)$ [31, 32]. The HAP diffractogram showed three peaks, two intense peaks at $2 \theta=32^{\circ}$ which were assigned to (211) and (112) and one peak at $2 \theta=33^{\circ}$ which was attributed to (300) [33].

The Mt XRD pattern displayed an overall crystalline structure showing peaks at $2 \theta=6^{\circ}$ and $2 \theta=20^{\circ}$ which were attributed to (001) and (100) planes corresponding to quartz which is commonly found in clays [34]. The HAP-CTS-Mt film spectra showed HAP basal peaks at $2 \theta=32^{\circ}$ and $33^{\circ}$, which confirms the presence of the HAP molecule in the HAP-CTS-MT film. Also, Mt and CTS 

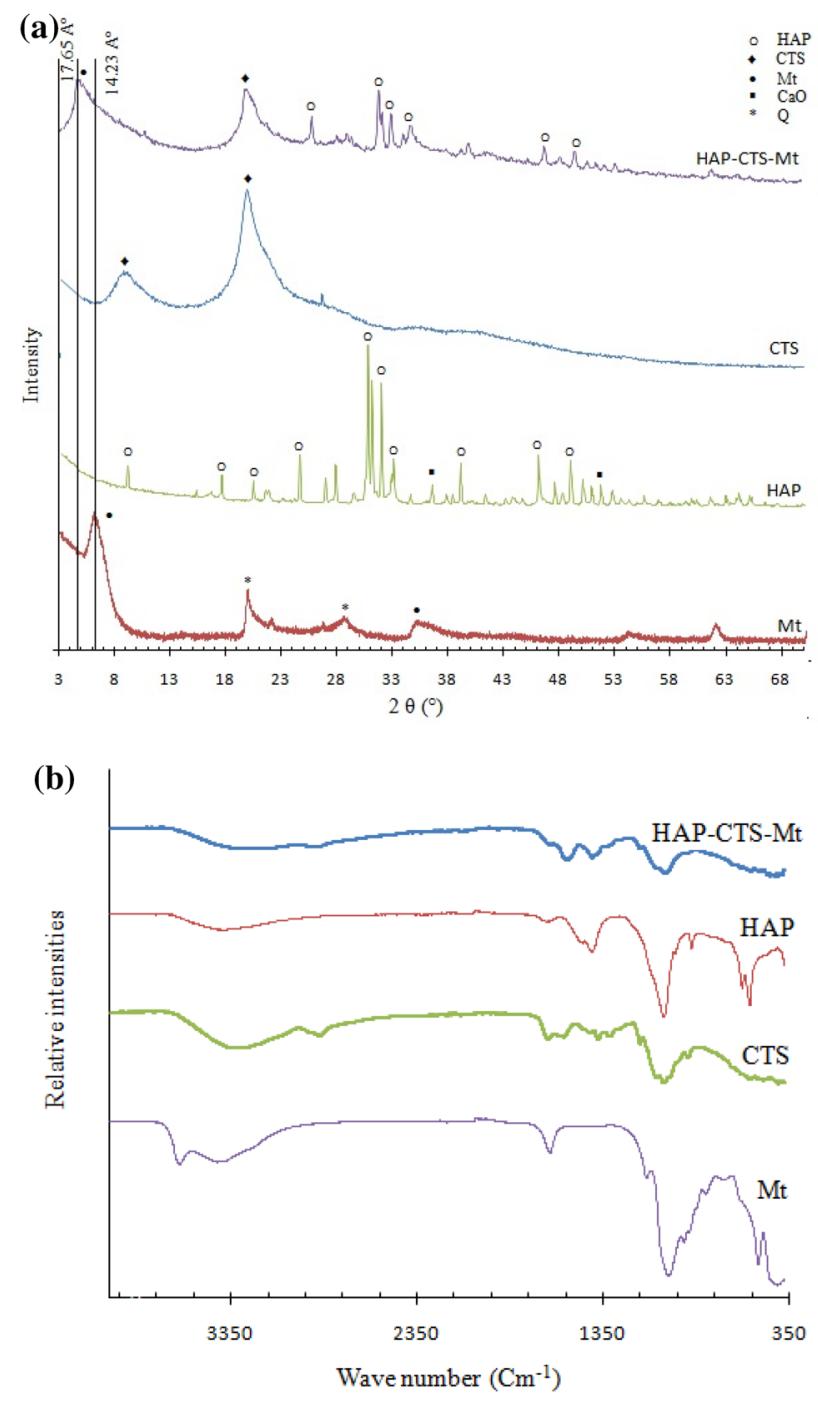

Fig. 1 a XRD patterns and $\mathbf{b}$ FT-IR spectra of samples characteristic peaks appeared at $2 \theta=20^{\circ}$, indicating the presence of CTS and Mt molecules in the HAP-CTS-Mt film. The basal peak of Mt had shifted from 6.2 to 5.0, which changes the $d_{001}$ from $14.23^{\circ} \mathrm{A}$ to $17.65^{\circ} \mathrm{A}$. The $3.42^{\circ} \mathrm{A}$ increase in $\mathrm{d}_{001}$ indicates the formation of intercalated CTS-HAP/Mt structure. Scheme 1 presents the possible interactions between chitosan, Mt and HAP.

Figure $1 \mathrm{~b}$ shows the FITR spectra of HAP, CTS, Mt powders and HAP-CTS-Mt thin film. CTS IR spectra showed peaks at $3363 \mathrm{~cm}^{-1}$ assigned to $\mathrm{O}-\mathrm{H}$ stretching band at $3284 \mathrm{~cm}^{-1}$ corresponding to $\mathrm{N}-\mathrm{H}$ stretching band. However, the HAP-CTS-Mt film spectra exhibited a broader $\mathrm{N}-\mathrm{H}$ stretching, indicating a protonation of amino. groups of CTS by the overlapping of $\mathrm{O}-\mathrm{H}$ large band with $\mathrm{N}-\mathrm{H}$. In addition, the $\mathrm{N}-\mathrm{H}$ band of $\mathrm{CTS}$ powder had shifted from 1561 to $1536 \mathrm{~cm}^{-1}$ in HAP-CTS-Mt film [35]. The characteristic bands of C-O-C linkage were observed at $1150 \mathrm{~cm}^{-1}$ and $1034 \mathrm{~cm}^{-1}$. The $\mathrm{C}-\mathrm{N}$ band appeared at $898 \mathrm{~cm}^{-1}[36$, 37].The HAP spectra showed characteristic phosphate peaks at $1021 \mathrm{~cm}^{-1}$ and $961 \mathrm{~cm}^{-1}$ which shifted to the right in the HAP-CTS-Mt film spectra. $\mathrm{CO}_{3}{ }^{2-}$ bands appeared at $1406 \mathrm{~cm}^{-1}$.The $\mathrm{N}-\mathrm{H}$ bending had also shifted from $1458 \mathrm{~cm}^{-1}$ to $1536 \mathrm{~cm}^{-1}$ in the HAP-CTS-Mt film due to interactions between the amide group of $\mathrm{CTS}$ and $\mathrm{PO}_{4}{ }^{3-}$ of $\operatorname{HAP}[38,39]$. The FT-IR spectra of Mt showed elongating of $\mathrm{O}-\mathrm{H}$ of $\mathrm{H}_{2} \mathrm{O}$ at $3624 \mathrm{~cm}^{-1}$. Bands at $3433 \mathrm{~cm}^{-1}$ and $1633 \mathrm{~cm}^{-1}$ were assigned to $\mathrm{O}-\mathrm{H}$ stretching of $\mathrm{H}_{2} \mathrm{O}$. The band at $514 \mathrm{~cm}^{-1}$ was allocated to Si-O-Al deformation and the Si-O-Si band of Mt powder [40, 41]. FT-IR spectrum of HAP-CTS-Mt thin film showed similar characteristic band of the HAP, CTS and Mt with some shifts and with low intensity. The HAP-CTS-Mt spectrum showed similar bands to CTS spectra; this is due to the high amount of CTS in the HAP-CTS-Mt film. The analysis given above showed no. destruction of materials during the film preparation.
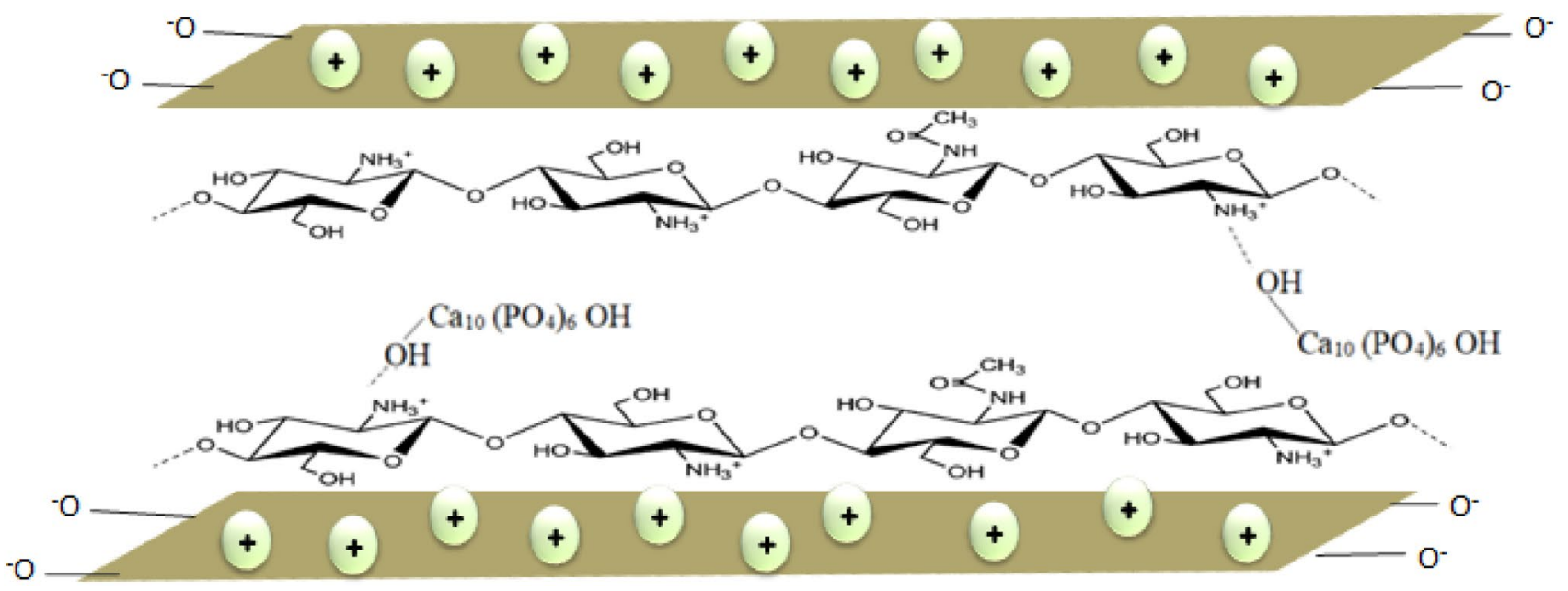

Scheme 1 Schematic diagram of HAP-CTS-Mt thin film. 


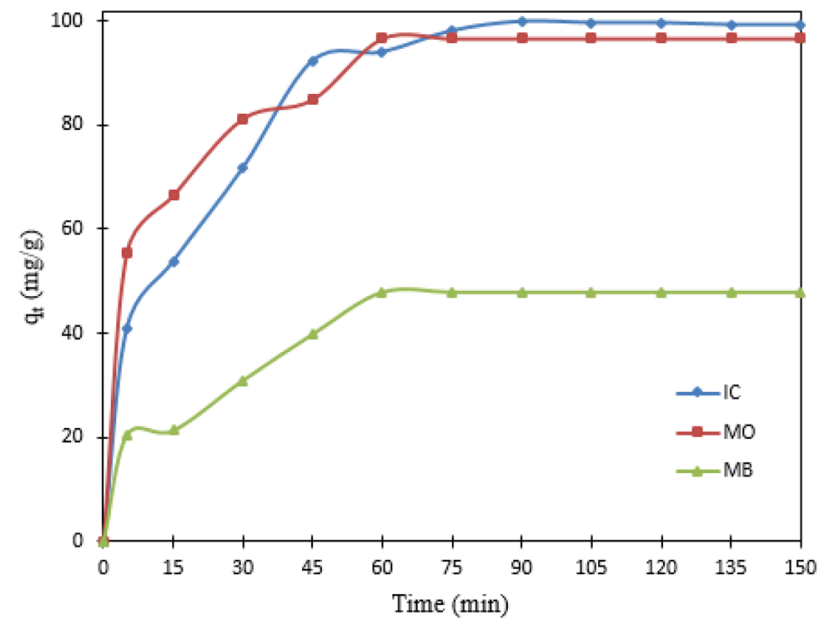

Fig. 2 Effect of contact time on the dye adsorption onto HAPCTS-Mt thin film $\left(C_{0}=20 \mathrm{mg} / \mathrm{L}\right.$ for $I C$ and $M B, C_{0}=50 \mathrm{mg} / \mathrm{L}$ for $\mathrm{MO}$, $\mathrm{m}_{\text {HAP-CTS-Mt }}=0.2 \mathrm{~g} / \mathrm{Lfor} \mathrm{IC}$ and $\mathrm{MB}, \mathrm{m}_{\text {HAP-CTS-Mt }}=0.5 \mathrm{~g} / \mathrm{Lfor} \mathrm{MO}$, $\mathrm{T}=$ room temperature

\section{Effect of contact time}

Figure 2 indicates the adsorption capacities of IC, MO, and MB onto HAP-CTS-Mt as function of time. The adsorption capacity was relatively rapid in the first $5 \mathrm{~min}$ due to the higher number of vacant sites of HAP-CTS-Mt in the first minutes and then slowed down to reach equilibrium after $90 \mathrm{~min}, 60 \mathrm{~min}$ and $60 \mathrm{~min}$ of contact for IC, MO, and MB, respectively. At the equilibrium, the adsorption capacities were registered at $99.87 \mathrm{mg} / \mathrm{g}, 96.65 \mathrm{mg} / \mathrm{g}$ and $47.92 \mathrm{mg} / \mathrm{g}$ for $\mathrm{IC}, \mathrm{MO}$, and $\mathrm{MB}$, respectively.

\subsection{Effect of adsorbent amount}

Figure 3 shows the effect of varying the adsorbent dosage from 0 to $1.5 \mathrm{~g} / \mathrm{L}$ of HAP-CTS-Mt on the adsorption of the three dyes. At dosage less than $0.2 \mathrm{~g} / \mathrm{L}$ for IC, MB and $0.5 \mathrm{~g} / \mathrm{L}$ for $\mathrm{MO}$, the removal percentages increased rapidly, and then became constant to achieve equilibrium at $0.2 \mathrm{~g} / \mathrm{L}$ for IC and MB and $0.5 \mathrm{~g} / \mathrm{L}$ for $\mathrm{MO}$; due to the availability of free adsorption sites on the adsorbent surface [42]. Consequently, $0.2 \mathrm{~g} / \mathrm{L}$ was chosen as the optimal dose for the adsorption of $\mathrm{IC}$ and $\mathrm{MB}$, whereas, $0.5 \mathrm{~g} / \mathrm{L}$ was considered as optimal dose for the adsorption of $\mathrm{MO}$ onto HAP-CTS-Mt. This difference of optimal dose can be attributed to the number of benzene in the dye structure as explained by Ocholi et al. [43].

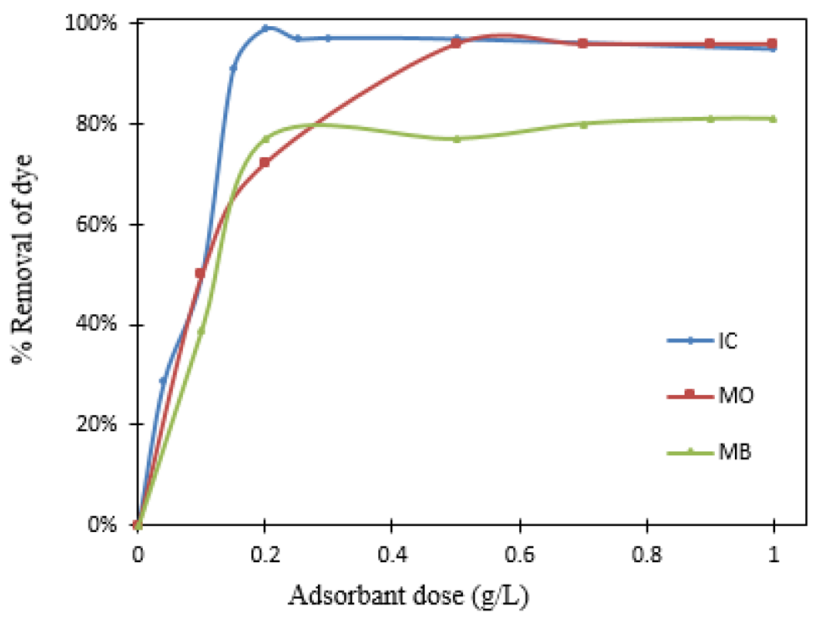

Fig. 3 Effect of adsorbent dosage on the removal of dyes onto HAP-CTS-Mt thin film $\left(C_{0}=20 \mathrm{mg} / \mathrm{L}\right.$ for $\mathrm{IC}$ and $\mathrm{MB}$ and $50 \mathrm{mg} / \mathrm{L}$ for $\mathrm{MO}, \mathrm{pH}=6$ and $\mathrm{T}=$ room temperature $(293 \mathrm{~K})$

\subsection{Effect of initial pH}

The $\mathrm{pH}$ point zero charge (PZC) corresponds to the $\mathrm{pH}$ at which the HAP-CTS-Mt surface has no. charge. The PZC was found to be 6.24 (see Fig. 4). This indicates that at $\mathrm{pH}$ values less than 6.24, the surface of HAP-CTS-Mt is positive while at $\mathrm{pH}$ values higher than 6.24 , the surface of HAP-CTS-Mt is negatively charged. Hence the adsorption of dyes charged negatively was favorable at $\mathrm{pH}$ values around or under 6.24 , whereas at $\mathrm{pH}$ values above 6.24 , the adsorption of dyes charged positively was effective (Fig. 4).

The low adsorption capacity of $\mathrm{IC}, \mathrm{MO}$ and $\mathrm{MB}$ using HAP-CTS-Mt registered at $\mathrm{pH}=4$ can be explained according to two hypotheses; first, the lower adsorption capacity may be due to the chitosan solubilization which happens for pHs lower than 6 [44]. Second, the pKa of MO and MB are $4.4-5.5$ and 3.8 respectively, indicating that the $\mathrm{MO}$ and $M B$ were protonated, that decrease the fixation of the $M O$ and MB into HAP-CTS-Mt thin film $[45,46]$.

The removal rate of IC, MO and MB by HAP-CTS-Mt rapidly increased at $\mathrm{pH}$ values ranged from 5 to 6.24. However, adsorption capacities for IC and MO decreased by increasing $\mathrm{pH}$ from 8 to 10 ; creating electrostatic repulsion between the negatively charged surface of HAP-CTS-Mt and the anionic $\mathrm{IC}$ and $\mathrm{MO}$ molecules; this resulted in low adsorption capacities of IC and MO [47]. Contrariwise, for $\mathrm{MB}$, the adsorption capacity rose by increasing $\mathrm{pH}$; this is due to the negatively charged surface of HAP-CTS-Mt 

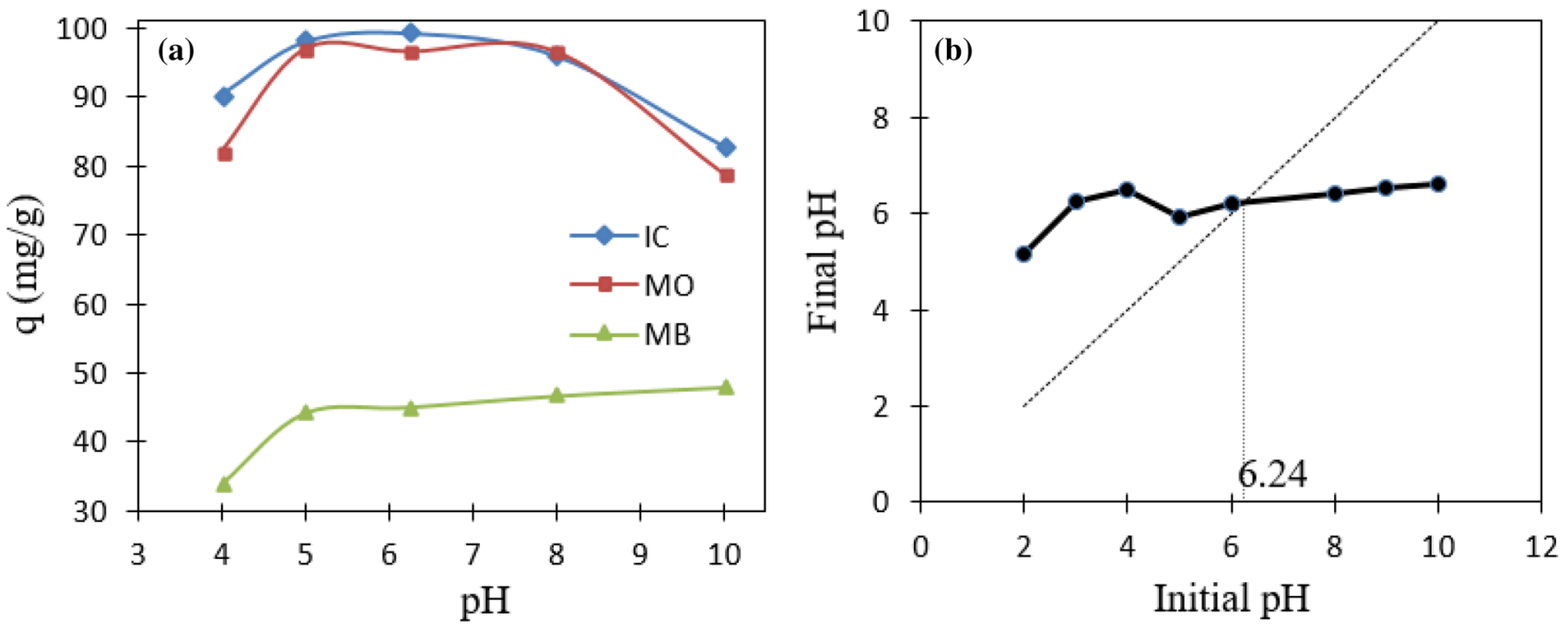

Fig. 4 a Effect of $\mathrm{pH}$ on the removal of dyes onto HAP-CTS-Mt thin film $\left(\mathrm{C}_{0}=20 \mathrm{mg} / \mathrm{L}\right.$ for IC and $\mathrm{MB}$ and $50 \mathrm{mg} / \mathrm{L}$ for $\mathrm{MO}$, $m_{\text {HAP-CTS-Mt }}=0.2 \mathrm{~g} / \mathrm{Lfor} I \mathrm{IC}$ and MB, $\mathrm{m}_{\text {HAP-CTS-Mt }}=0.5 \mathrm{~g} / \mathrm{Lfor} \mathrm{MO}$, and T=room temperature $(293 \mathrm{~K})$, b the point zero charge of HAP-CTS-Mt

at $\mathrm{pH}$ values higher than 8 , facilitating the association between the cationic charge of MB and the thin film.

\subsection{Proposed adsorption mechanism}

The adsorption mechanism of IC, MO and MB using HAP-CTS-Mt thin film can be interpreted by the electrostatic interactions between the negatively charged of IC, MO dyes and positively charged surface of HAP-CTS-Mtthin film at $\mathrm{pH}$ values less than 6.24. However, the adsorption of MB using this adsorbent can be conducted to electrostatic interactions between the positive charge of MB and negative charge of HAP-CTS-Mt at $\mathrm{pH}$ values higher than 6.24 (see Scheme 2).

\subsection{Effect of initial dye concentration}

The effect of initial IC, MO and MB dyes concentrations was studied form 10 to $200 \mathrm{mg} / \mathrm{L}$ (Fig. 5). It is observed that a rise in the initial IC, $M O$ and $M B$ dyes concentrations lead to a rise in the adsorption capacities, IC from 56 to $250 \mathrm{mg} / \mathrm{g}$, MO from (19.42 to $137.48 \mathrm{mg} / \mathrm{g}$ ) and MB from $(39.63$ to $157 \mathrm{mg} / \mathrm{g})$. This is due to the rise in the driving force of the concentration gradient with enhancing the initial IC, MO and MB concentration [48-50].

\subsection{Effect of temperature}

The temperature of $\mathrm{IC}, \mathrm{MO}$ and $\mathrm{MB}$ solutions was varied to test the effect of this factor on the adsorption phenomena (Fig. 6). A decrease from 99.29 to $89.5 \mathrm{mg} / \mathrm{g}, 96.63$ to
$79.44 \mathrm{mg} / \mathrm{g}$ and 45.04 to $40.1 \mathrm{mg} / \mathrm{g}$ of the adsorption capacity was observed for IC, MO, and MB respectively, as increasing temperature, indicating that the adsorption reaction was exothermic. Such behaviors may be due to the bonding between $\mathrm{IC}, \mathrm{MO}, \mathrm{MB}$ molecules and the active sites of HAP-CTS-Mt which weakened when the temperature increased [51].

\subsection{Adsorption kinetics and isotherms study}

The kinetic study provides important information about the mechanism of IC, $M O$ and $M B$ adsorption onto HAP-CTS-Mt. The kinetic parameters were determined using pseudo-first-order and pseudo-second-order equations [52-54] at optimum dose of HAP-CTS-Mt, pH, initial dyes concentration and temperature for batch adsorption process. The nonlinear equations of the two models are presented in Table 1. The most-fit model was selected from the nonlinear regression correlation coefficient values $\left(R^{2}\right)$. The modelparameters were evaluated using Orign 8.0 software. The main statistical criteria were the regression coefficient $\left(R^{2}\right)$, and the chi-square analysis $\left(X^{2}\right)$ [54].

The adsorption capacities, constants rates, and regression coefficients are depicted in Table 2.The correlation coefficient close to unity, and experimental values for $q_{e}$ are similar to the calculated ones (Table 2) indicate that the adsorption of $\mathrm{IC}, \mathrm{MO}$ and MB using HAP-CTS-Mt is described by the pseudo-second-order model (See Fig. 7). In this work, three important isotherm models, namely Freundlich [55, 56], Langmuir [57-59] and Dubinin-Radushkevich [60] were studied; the Langmuir isotherm model 

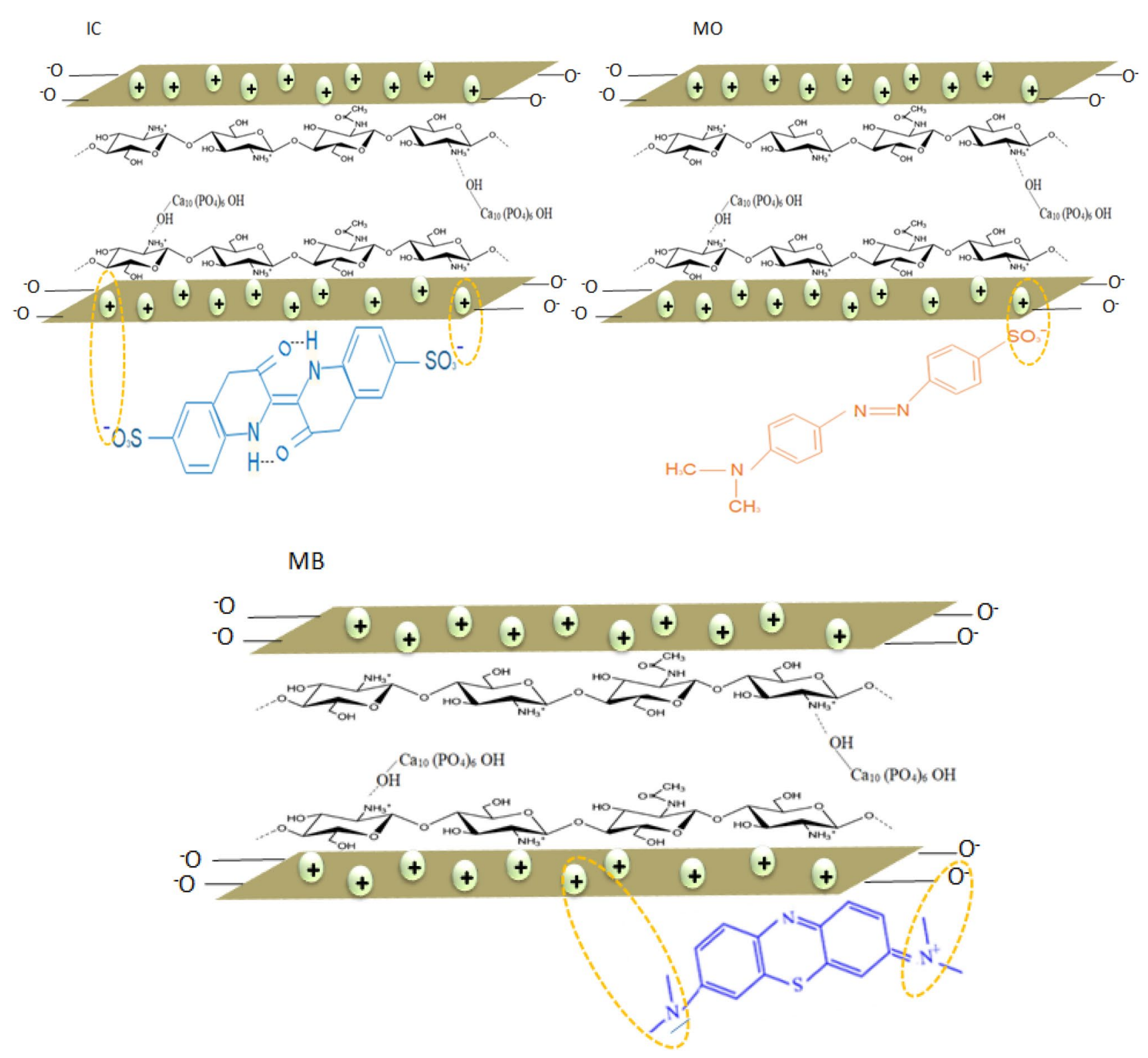

Scheme 2 Schematic diagram possible for the adsorption of IC, MO and MB using HAP-CTS-Mt thin film

is founded on the assumption of monolayer of molecules on the adsorbent surface. However, the Freundlich model shows the heterogeneity for adsorbate-adsorbent interactions, and the Dubinin-Radushkevich model is used to predict the physical or chemical nature of adsorption by calculating sorption energy. The equations describing the three isotherms models are listed in Table1.

The isotherm constants for the Langmuir, the Freundlich and the Dubinin-Radushkevich isotherm models have been calculated using nonlinear regression with the help of Origin (Version 8) software program. The results for the three isotherms models are presented in Fig. 8.The values of different parameters are presented in Table 3. The adsorption of the tree dyes using the prepared film followed the Langmuir model. The values of $\mathrm{R}^{2}$ of this model are superior to 0.98 for the studied dyes showing that the Langmuir model fits the adsorption process of IC, MO, and MB onto HAP-CTS-Mt. The E values are calculated to 


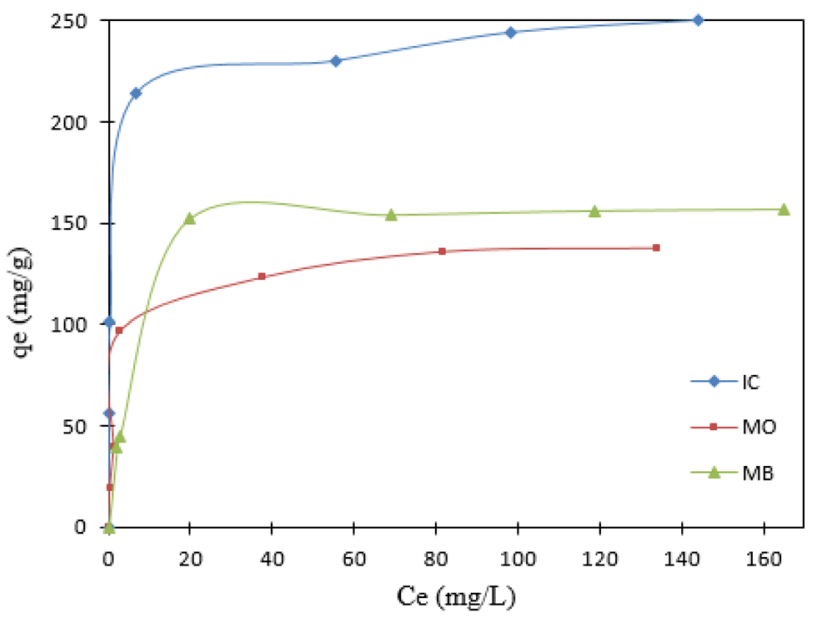

Fig. 5 Effect of concentration on the removal of dyes onto HAP-CTS-Mt thin film (m $m_{\text {HAP-CTS-Mt }}=0.2 \mathrm{~g} / \mathrm{L}$ for $I C$ and $M B$, $\mathrm{m}_{\text {HAP-CTS-Mt }}=0.5 \mathrm{~g} / \mathrm{Lfor} \mathrm{MO}$ and $\mathrm{T}=$ room temperature $(293 \mathrm{~K})$

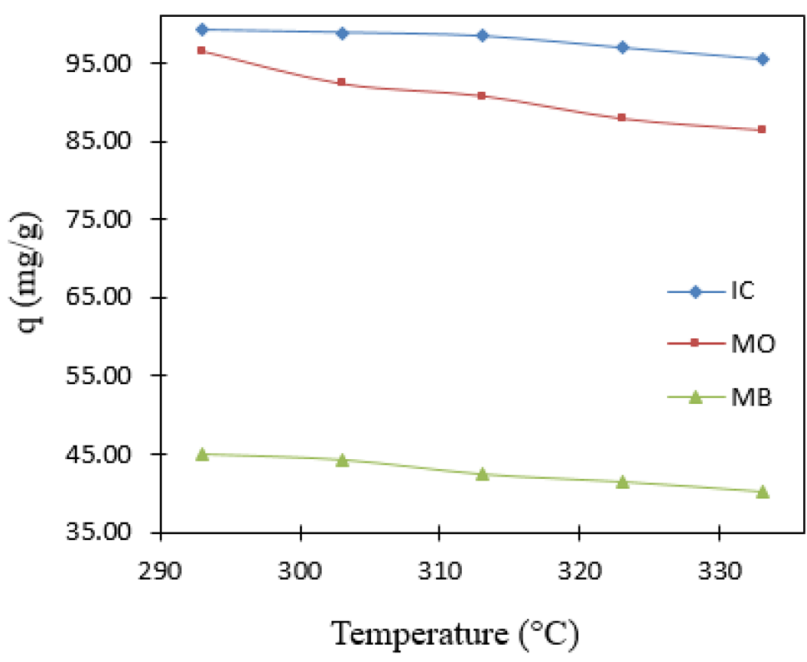

Fig. 6 Effect of temperature on the removal of dyes onto HAP-CTS-Mt thin film (m $m_{\text {HAP-CTS-Mt }}=0.2 \mathrm{~g} / \mathrm{Lfor} I \mathrm{IC}$ and MB, $\mathrm{m}_{\text {HAP-CTS-Mt }}=0.5 \mathrm{~g} / \mathrm{Lfor} \mathrm{MO}$ and $\mathrm{C}_{0}=20 \mathrm{mg} / \mathrm{L}$ for $\mathrm{IC}$ and $\mathrm{MB}$ and $50 \mathrm{mg} / \mathrm{L}$ for MO) determine the type of adsorption process. If $8<\mathrm{E}<16 \mathrm{~kJ} /$ $\mathrm{mol}$, the adsorption process is a chemical adsorption, however, if $\mathrm{E}<8 \mathrm{~kJ} / \mathrm{mol}$, the adsorption process is physical in nature. In this study, the values of the $E$ determined from Dubinin-Radushkevich equation are $<8 \mathrm{~kJ} / \mathrm{mol}$, indicating that the adsorption of the IC, MO and MB by HAP-CTS-Mt is physical in nature.

\subsection{Thermodynamic parameters}

Section 3.7 revealed that the adsorption capacity decreases by increasing solution temperature, which implies the exothermic nature of adsorption [61]. The thermodynamic parameters were evaluated using Gibbs free energy $\left(\Delta G^{\circ}\right)$, enthalpy $\left(\Delta H^{\circ}\right)$ and entropy $\left(\Delta S^{\circ}\right)$ are evaluated using equations below $[62,63]$ :

$\Delta \mathrm{G}^{\circ}=-\mathrm{RT} \ln \mathrm{K}_{\mathrm{a}} ;$

$\mathrm{K}_{\mathrm{a}}=\frac{(1000 \cdot \text { molecular weight }) \cdot K_{L} \cdot[\text { Adsorbate }]}{\text { coefficient of activity }}$;

$\operatorname{lnK}_{\mathrm{a}}=-\frac{\Delta \mathrm{H}^{\circ}}{\mathrm{RT}}+\frac{\Delta \mathrm{S}^{\circ}}{\mathrm{R}}$

$\mathrm{R}(8.314 \mathrm{~J} / \mathrm{mol} \mathrm{K})$ is the constant of gas, $\mathrm{K}_{\mathrm{a}}$ is constant without unit also $T$ present the temperature (K). Several studies revealed that the equilibrium constant $\left(\mathrm{K}_{\mathrm{a}}\right)$ must be dimensionless in order to have accurate results regarding the Gibb's free energy [63]. The negative or positive values of $\Delta G^{\circ}$ indicate the spontaneity (or non-spontaneity) of the adsorption process [64]. The positive values of $\Delta S^{\circ}$ suggests that the organization of the adsorbate at the solid/ solution interface becomes more random, while negative value suggests the opposite fact. The positive values of enthalpy change $\Delta \mathrm{H}^{\circ}$ proposed that the adsorption process is endothermic, however the negative values of $\Delta \mathrm{H}^{\circ}$ suggest that the adsorption is exothermic [65]. The values of $\Delta \mathrm{H}^{\circ}$ and $\Delta \mathrm{S}^{\circ}$ were recapitulated in Table 4.

Table 1 The equations and constant parameters for the studying models

\begin{tabular}{|c|c|}
\hline Model & Parameters \\
\hline $\begin{array}{l}\text { Pseudo-first-order model } \\
\mathrm{q}_{\mathrm{t}}=\mathrm{q}_{\mathrm{e}}\left(1-\mathrm{e}^{-\mathrm{k}_{1} \mathrm{t}}\right)\end{array}$ & $\begin{array}{l}\mathrm{q}_{\mathrm{e}} \text { present the adsorption capacity at equilibrium and } \mathrm{q}_{\mathrm{t}} \text { at the time, however, } \mathrm{k}_{1}\left(\mathrm{~min}^{-1}\right) \text { is the rate constant of pseudo-first-order } \\
\text { model }\end{array}$ \\
\hline $\begin{array}{l}\text { Pseudo-second-order model } \\
\mathrm{q}_{\mathrm{t}}=\frac{\mathrm{k}_{2} \mathrm{q}_{\mathrm{e}}^{2} \mathrm{t}}{1+\mathrm{k}_{2} \mathrm{q}_{\mathrm{e}} \mathrm{t}}\end{array}$ & $\begin{array}{l}\mathrm{q}_{\mathrm{e}} \text { and } \mathrm{q}_{\mathrm{t}} \text { presents the adsorption capacities at equilibrium and at the time, } \mathrm{k}_{2}\left(\mathrm{~g} \cdot \mathrm{mg}^{-1} \mathrm{~min}^{-1}\right) \text { is the rate constant of pseudo-second- } \\
\text { order model }\end{array}$ \\
\hline $\begin{array}{l}\text { Langmuir model } \\
\mathrm{q}_{\mathrm{e}}=\frac{\mathrm{q}_{\mathrm{m}} \mathrm{K}_{\mathrm{L}} \mathrm{C}_{\mathrm{e}}}{1+\mathrm{K}_{\mathrm{L}} \mathrm{C}_{\mathrm{e}}}\end{array}$ & $\begin{array}{l}\mathrm{q}_{\mathrm{e}}(\mathrm{mg} / \mathrm{g}) \text { and } \mathrm{C}_{\mathrm{e}}(\mathrm{mg} / \mathrm{L}) \text { are the capacity of adsorption and dye concentration at equilibrium respectively, } \mathrm{q}_{\mathrm{m}} \text { is the maximum capac- } \\
\text { ity and } \mathrm{K}_{\mathrm{L}}(\mathrm{L} / \mathrm{mg}) \text { is constant of Langmuir model }\end{array}$ \\
\hline Dubinin-Radushkevich & $\mathrm{q}_{\mathrm{e}}$ and $\mathrm{q}_{\mathrm{s}}$ are the capacity of adsorption at equilibrium and maximum respectively, and $\mathrm{K}_{\mathrm{ad}}$ is free energy of adsorption per mole \\
\hline$q_{e}=q_{s} \exp ^{\left(-K_{a d} \varepsilon^{2}\right)}$ & $\begin{array}{l}\text { of adsorbate }\left(\mathrm{mol}^{2} / \mathrm{J}^{2}\right) \text { and } \varepsilon \text { Polanyi potential that is calculated using this equation: } \varepsilon=\mathrm{RT} . \ln \left(1+\left(\frac{1}{\mathrm{C}_{\mathrm{e}}}\right)\right) \text {; where, } \mathrm{R} \text { is the } \\
\text { universal gas constant }(8.314 \mathrm{~J} / \mathrm{mol} . \mathrm{K}), \mathrm{T} \text { is the temperature in Kelvin }(\mathrm{K}) \text { and } \mathrm{E} \text { the mean adsorption energy that is calculated using } \\
\text { this equation: } E=\frac{1}{\sqrt{2 K_{\text {sd }}}}\end{array}$ \\
\hline $\begin{array}{l}\text { Freundlich model } \\
\mathrm{q}_{\mathrm{e}}=\mathrm{K}_{\mathrm{F}} \mathrm{C}_{\mathrm{e}}^{\frac{1}{n}}\end{array}$ & $\begin{array}{l}1 / \mathrm{n} \text { present the heterogeneity factor, } \mathrm{K}_{\mathrm{F}}(\mathrm{mg} / \mathrm{g}(\mathrm{L} . \mathrm{mg}))^{1 / \mathrm{n}} \text { is the adsorption capacity related to Freundlich isotherm. Values of } \mathrm{n}<1 \text {, } \\
1<\mathrm{n}<2 \text { and } 2<\mathrm{n}<10 \text { show poor, difficult and good adsorption characteristics, respectively }\end{array}$ \\
\hline
\end{tabular}


Table 2 The pseudo-first-order kinetics, and the pseudo-second-order kinetics for dyes adsorption onto HAP-CTS-Mt

\begin{tabular}{|c|c|c|c|c|c|}
\hline & & IC & & MO & MB \\
\hline & $\mathrm{q}_{\mathrm{e}}$ Experimental & 99.872 & & 96.641 & 47.914 \\
\hline \multirow[t]{4}{*}{ Pseudo first-order } & qe calcul (mg/g) & 97.553 & & 90.057 & 46.094 \\
\hline & $\mathrm{K}_{1}\left(\min ^{-1}\right)$ & 0.058 & & 0.136 & 0.049 \\
\hline & $\mathrm{R}^{2}$ & 0.95 & & 0.93 & 0.959 \\
\hline & $x^{2}$ & 61.436 & & 73.794 & 11.263 \\
\hline \multirow[t]{4}{*}{ Pseudo second-order } & qe calcul (mg/g) & 102.131 & & 99.16 & 48.551 \\
\hline & $\mathrm{K}_{2}(\mathrm{~g} / \mathrm{mg} \mathrm{min})$ & & $6.52 . \times 10^{-4}$ & 0.001 & 0.001 \\
\hline & $\mathrm{R}^{2}$ & 0.981 & & 0.975 & 0.989 \\
\hline & $x^{2}$ & 35.557 & & 25.978 & 5.634 \\
\hline
\end{tabular}
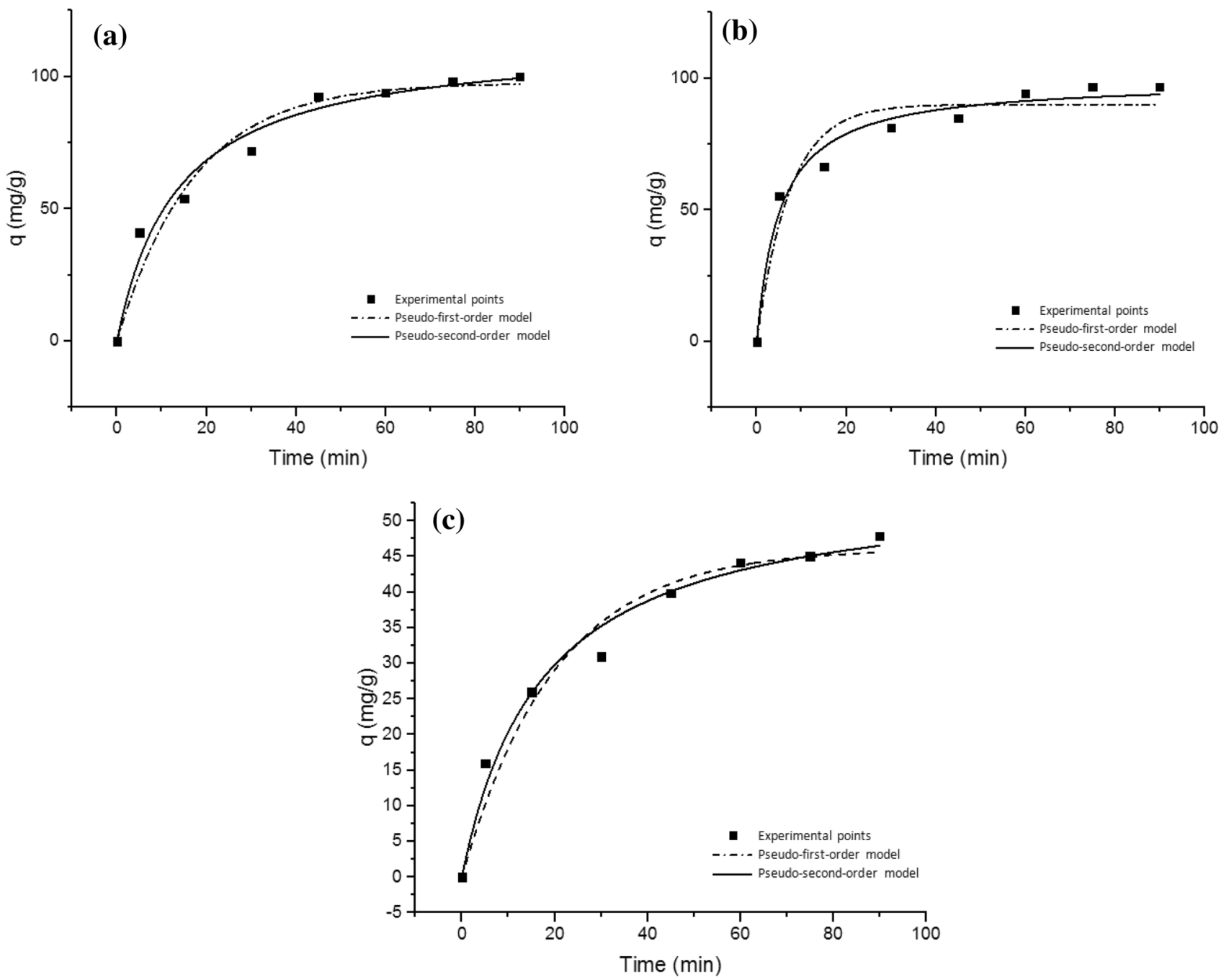

Fig. 7 Experimental data and the fitted non-linear forms of pseudo-first-order kinetics, and the pseudo-second-order kinetics for dyes adsorption onto HAP-CTS-Mt 

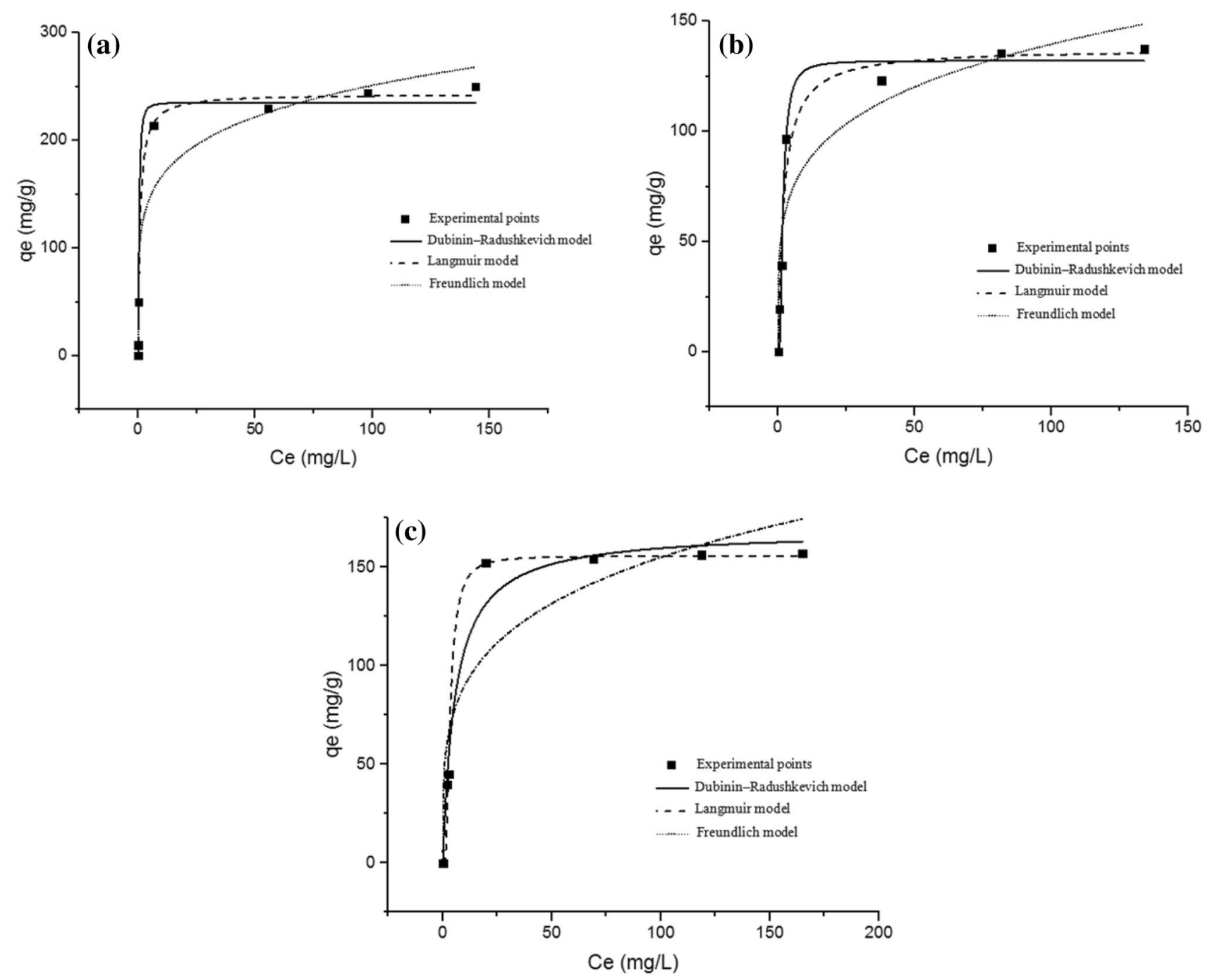

Fig. 8 Non linear fitting of the Dubinin-Radushkevich, Langmuir and Freundlich isotherms models for the adsorption of IC, MO and MB using HAP-CTS-Mt thin film

Table 3 Isotherm constants and correlation coefficients for the adsorption of dyes on HAP-CTS-Mt

\begin{tabular}{lllcc}
\hline & & $\mathrm{IC}$ & $\mathrm{MO}$ & $\mathrm{MB}$ \\
\hline Langmuir model & $\mathrm{q}_{\mathrm{m}}(\mathrm{mg} / \mathrm{g})$ & 243.18 & 137.5 & 168.52 \\
& $\mathrm{~K}_{\mathrm{L}}(\mathrm{L} / \mathrm{mg})$ & 1.21 & 0.49 & 0.178 \\
& $2 \mathrm{~N}$ & 52.6 & 99.83 & 124.07 \\
& $\mathrm{R}^{2}$ & 0.996 & 0.98 & 0.993 \\
Freundlich model & $\mathrm{K}_{\mathrm{F}}(\mathrm{mg} / \mathrm{g}(\mathrm{L} / \mathrm{mg}))^{(1 / n)}$ & 110.27 & 51.69 & 52.21 \\
& $\mathrm{~N}$ & 5.59 & 4.63 & 4.23 \\
& $2 \mathrm{~N}$ & 1145.51 & 392.65 & 716.49 \\
Dubinin-Radushkevich & $\mathrm{R}^{2}$ & 0.915 & 0.883 & 0.85 \\
& $\mathrm{qs}(\mathrm{mg} / \mathrm{g})$ & 235.17 & 132.11 & 155.77 \\
& $2 \mathrm{~N}$ & 155.88 & 96.31 & 30.42 \\
& $\mathrm{~K}_{\mathrm{ad}}\left(\mathrm{mol}{ }^{2} / \mathrm{J}^{2}\right)$ & $2.04 . \times 10^{-4}$ & 0.00146 & 0.0043 \\
& $\mathrm{E}\left(\mathrm{J} / \mathrm{mol}^{2}\right)$ & 49.507 & 18.5 & 10.78 \\
& $\mathrm{R}^{2}$ & 0.988 & 0.971 & 0.974
\end{tabular}


Table 4 Thermodynamic parameters for the adsorption of dyes onto HAP-CTS-Mt

\begin{tabular}{llllllll}
\hline & $\Delta \mathrm{H}^{\circ} \mathrm{kJ} / \mathrm{mol}$ & $\Delta \mathrm{S}^{\circ} \mathrm{J} / \mathrm{mol} \mathrm{K}$ & \multicolumn{2}{l}{$\Delta \mathrm{G}^{\circ} \mathrm{kJ} / \mathrm{mol}$} \\
\cline { 3 - 7 } & & & $293 \mathrm{~K}$ & $303 \mathrm{~K}$ & $313 \mathrm{~K}$ & $323 \mathrm{~K}$ & $333 \mathrm{~K}$ \\
\hline $\mathrm{IC}$ & $-54,42$ & $-66,29$ & $-35,40$ & $-34,10$ & $-33,14$ & $-32,95$ & $-32,75$ \\
MO & $-45,65$ & $-49,76$ & $-31,46$ & $-30,15$ & $-29,88$ & $-29,57$ & $-29,33$ \\
MB & $-17,83$ & 36,44 & $-28,48$ & $-29,04$ & $-29,10$ & $-29,61$ & $-30,02$ \\
\hline
\end{tabular}

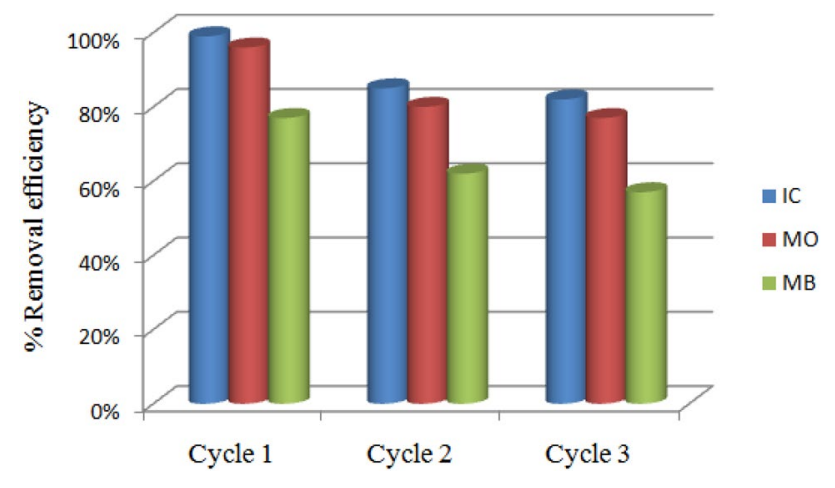

Fig. 9 Reusability study of HAP-CTS-Mt with IC, MO and MB

The $\Delta G^{\circ}$ values indicate that the adsorption of the three dyes using HAP-CTS-Mt was spontaneous and favorable; the rise in $\Delta G^{\circ}$ with increasing temperature indicates that the adsorption is favorable at $293 \mathrm{~K}$. The $\Delta \mathrm{H}$ negative values $(-54.42 \mathrm{~kJ} / \mathrm{mol}$. K; $-45.65 \mathrm{~kJ} / \mathrm{mol} \mathrm{K}$ and $-17.83 \mathrm{~kJ} / \mathrm{mol}$. $\mathrm{K}$ for IC, MO, and $\mathrm{MB}$, respectively) confirm the exothermic nature of adsorption [66]. The calculated $\Delta S^{\circ}$ value was found to be negative; this corresponds to a decrease in the degree of freedom of the adsorbed species. However, the $\Delta S^{\circ}$ value of MB dye adsorption onto HAP-CTS-Mt was found to be positive which indicates a slight increase in disorder at the solid-adsorbate interface during adsorption process.

\subsection{Regeneration study}

The regeneration of the adsorbent is an important step in order to recover the dye and reuse the prepared adsorbent in several cycles of adsorption [67]. After adsorption at optimal conditions regarding each dye the HAP-CTS-Mt/dye was washed several times with distilled water to remove any unadsorbed dyes. Thereafter, the HAP-CTS-Mt/dye was desorbed using 3.0 M NaOH. The regenerated HAP-CTS-Mt was washed with distilled water, dried in open air and reutilized thereafter. The adsorption-desorption of HAP-CTS-Mt for the three dyes was presented in Fig. 9.

It was observed that the removal of dyes was efficient up to 3 cycles for the three studied dyes, which implies that the film can be utilized several times before complete exhaustion.

\subsection{Comparison study of the adsorption of IC, MO and MB using different adsorbents}

The adsorption capacities of $I C, M O$ and $M B$ onto HAP-CTS-Mt thin film have been compared with those of others reported in the literature as presented in Table 5. It is notice that HAP-CTS-Mt has higher adsorption capacities among other adsorbent such as chitosan, chitosan/ actived carbon, chitosane biomass, magnetic chitosane and Alginate-Chitosan-Montmorillonite (Table 5).
Table 5 Maximum loading capacities (Langmuir model) for IC, MO and MB adsorption

\begin{tabular}{llll}
\hline Adsorbent & Adsorbate & q (mg/g) & References \\
\hline Chitosan & IC & 71.28 & {$[68]$} \\
Chitosan/activated carbon & IC & 208.33 & {$[69]$} \\
Chitosane biomass & MO & 29 & {$[70]$} \\
Magnetic chitosan & MB & 60.4 & {$[71]$} \\
Alginate-Chitosan-Montmorillonite & MB & 137.15 & {$[72]$} \\
Montmorillonite nanosheets/chitosan & MB & 530 & {$[73]$} \\
HAP-CTS-Mt & IC & 250 & Current study \\
HAP-CTS-Mt & MO & 142.86 & Current study \\
HAP-CTS-Mt & MB & 166.67 & Current study \\
\hline
\end{tabular}




\section{Conclusion}

In this work, the HAP-CTS-Mt film was elaborated and characterized by FTIR and XRD. The adsorption of IC, MO, and $\mathrm{MB}$ from aqueous solution onto HAP-CTS-Mt was also examined. The results showed that the HAP-CTS-Mt film was able to remove IC, MO, and $\mathrm{MB}$ dyes. The adsorption of the three studied dyes using this new film followed the Langmuir isotherm model, with maximum adsorption capacityof $243.18 \mathrm{mg} / \mathrm{g}, 137.5 \mathrm{mg} / \mathrm{g}$ and 168.52 for IC, MO, and $M B$, respectively. The optimal adsorbent dose for IC and $\mathrm{MB}$ was $0.2 \mathrm{~g} / \mathrm{L}, 0.5 \mathrm{~g} / \mathrm{L}$ for $\mathrm{MO}$, At optimum concentration of $20 \mathrm{mg} / \mathrm{L}, 50 \mathrm{mg} / \mathrm{L}$ and $20 \mathrm{mg} / \mathrm{L}$ for $\mathrm{IC}, \mathrm{MO}$ and $M B$ respectively. The adsorption of $I C, M O$ and $M B$ was fitted by the pseudo-second order model. The adsorption of the tree dyes using HAP-CTS-Mt was exothermic and spontaneous. The possible mechanisms for the adsorption of IC, MO and MB using HAP-CTS-Mt thin film were also explained. Moreover, the desorption and regeneration experiments showed excellent adsorption performance even after 3 adsorption-desorption cycles.

Acknowledgements The authors would like to gratefully acknowledge the Faculty of Science Semlalia, University of Cadi Ayyad, Morocco for providing the XRD analysis.

\section{Compliance with ethical standards}

Conflict of interest On behalf of all authors, the corresponding author states that there is no. conflict of interest.

\section{References}

1. Al-Ghouti MA, Khraisheh MAM, Allen SJ, Ahmad MN (2003) The removal of dyes from textile wastewater: a study of the physical characteristics and adsorption mechanisms of diatomaceous earth. J Environ Manage 69(3):229-238. https://doi. org/10.1016/j.jenvman.2003.09.005

2. Muntean SG, Nistor MA, Andelescu AA, Radulescu-Grad ME, Ianos R (2016) Magnetite nanocomposites. Appl Decontam Wastewaters 61:6

3. Simu G, Funar-Timofei S, Hora S, Kurunczi L (2004) Experimental and theoretical study of the adsorption of a trisazo direct dye derived from 4,4'-diaminobenzanilide on a cellulose substrate. Mol Cryst Liq Cryst 416(1):97-104. https://doi. org/10.1080/15421400490478236

4. Muntean SG, Todea A, Bakardjieva S, Bologa C (2017) Removal of non benzidine direct red dye from aqueous solution by using natural sorbents: beech and silver fir. dWT 66:235-250. https:// doi.org/10.5004/dwt.2017.0154

5. Hashemian S, Mirshamsi M (2012) Kinetic and thermodynamic of adsorption of 2-picoline by sawdust from aqueous solution. J Ind Eng Chem 18(6):2010-2015. https://doi.org/10.1016/j. jiec.2012.05.020

6. Barka N, Assabbane A, Nounah A, Ichou YA (2008) Photocatalytic degradation of indigo carmine in aqueous solution by
TiO2-coated non-woven fibres. J Hazard Mater 152(3):10541059. https://doi.org/10.1016/j.jhazmat.2007.07.080

7. Lian L, Guo L, Guo C (2009) Adsorption of Congo red from aqueous solutions onto Ca-bentonite. J Hazard Mater 161(1):126131. https://doi.org/10.1016/j.jhazmat.2008.03.063

8. Othman I, Mohamed RM, Ibrahem FM (2007) Study of photocatalytic oxidation of indigo carmine dye on Mn-supported TiO2. J Photochem Photobiol, A 189(1):80-85. https://doi. org/10.1016/j.jphotochem.2007.01.010

9. Robinson T, McMullan G, Marchant R, Nigam P (2001) Remediation of dyes in textile effluent: a critical review on current treatment technologies with a proposed alternative. Biores Technol 77(3):247-255. https://doi.org/10.1016/S0960-8524(00)00080-8

10. Hameed BH, Ahmad AA, Aziz N (2007) Isotherms, kinetics and thermodynamics of acid dye adsorption on activated palm ash. Chem Eng J 133(1-3):195-203. https://doi.org/10.1016/j. cej.2007.01.032

11. Purkait MK, Maiti A, DasGupta S, De S (2007) Removal of congo red using activated carbon and its regeneration. J Hazard Mater 145(1-2):287-295. https://doi.org/10.1016/j.jhazm at.2006.11.021

12. Salman JM, Njoku VO, Hameed BH (2011) Adsorption of pesticides from aqueous solution onto banana stalk activated carbon. Chem Eng J 174(1):41-48. https://doi.org/10.1016/j. cej.2011.08.026

13. Popa A, Muntean SG, Paska OM, Iliescu S, Ilia G, Zhang Z (2011) Resins containing a-hydroxyphosphonic acid groups used for adsorption of dyes from wastewater. Polym Bull 66(3):419-432. https://doi.org/10.1007/s00289-010-0349-z

14. Păcurariu C, Paşka O, lanoş R, Muntean SG (2016) Effective removal of methylene blue from aqueous solution using a new magnetic iron oxide nanosorbent prepared by combustion synthesis. Clean Techn Environ Policy 18(3):705-715. https:// doi.org/10.1007/s10098-015-1041-7

15. Dotto GL, Cadaval TRS, Pinto LAA (2012) Preparation of bionanoparticles derived from Spirulina platensis and its application for $\mathrm{Cr}(\mathrm{VI})$ removal from aqueous solutions. J Ind Eng Chem 18(6):1925-1930. https://doi.org/10.1016/j.jiec.2012.05.005

16. Farajnezhad $H$, Gharbani $P$ (2012) Coagulation treatment of wastewater in petroleum industry using poly aluminum chloride and ferric chloride. Int J Res Rev Appl Sci 13(1):306-310

17. Maldonado $\mathrm{M}$ et al (2006) Partial degradation of five pesticides and an industrial pollutant by ozonation in a pilot-plant scale reactor. J Hazard Mater 138(2):363-369. https://doi. org/10.1016/j.jhazmat.2006.05.058

18. Alinsafi A et al (2005) Electro-coagulation of reactive textile dyes and textile wastewater. Chem Eng Process 44(4):461-470. https ://doi.org/10.1016/j.cep.2004.06.010

19. Dąbrowski A (2001) Adsorption-from theory to practice. Adv Coll Interface Sci 93(1-3):135-224. https://doi.org/10.1016/ S0001-8686(00)00082-8

20. Kim S, Park C, Kim T-H, Lee J, Kim S-W (2003) COD reduction and decolorization of textile effluent using a combined process. J Biosci Bioeng 95(1):102-105. https://doi.org/10.1016/S1389 -1723(03)80156-1

21. Dash M, Chiellini F, Ottenbrite RM, Chiellini E (2011) Chitosana versatile semi-synthetic polymer in biomedical applications. Prog Polym Sci 36(8):981-1014. https://doi.org/10.1016/j.progp olymsci.2011.02.001

22. Marques JL et al (2018) Removal of AI (III) and Fe (III) from binary system and industrial effluent using chitosan films. Int J Biol Macromol 120:1667-1673. https://doi.org/10.1016/j.ijbio mac.2018.09.135

23. Ding S-J (2007) Biodegradation behavior of chitosan/calcium phosphate composites. J Non-Cryst Solids 353(24-25):23672373. https://doi.org/10.1016/j.jnoncrysol.2007.04.020 
24. Liu H, Li H, Cheng W, Yang Y, Zhu M, Zhou C (2006) Novel injectable calcium phosphate/chitosan composites for bone substitute materials. Acta Biomater 2(5):557-565. https://doi.org/10.1016/j. actbio.2006.03.007

25. Ito M, Hidaka Y, Nakajima M, Yagasaki H, Kafrawy AH (1999) Effect of hydroxyapatite content on physical properties and connective tissue reactions to a chitosan-hydroxyapatite composite membrane. J Biomed Mat Res Off J Soc Biomater Jap Soc Biomat Austr Soc Biomater 45(3):204-208

26. Wang L, Wang A (2007) Adsorption characteristics of Congo Red onto the chitosan/montmorillonite nanocomposite. J Hazardous Mater 147(3):979-985. https://doi.org/10.1016/j.jhazm at.2007.01.145

27. Zhao Y et al (2020) Self-assembled gels of Fe-chitosan/montmorillonite nanosheets: dye degradation by the synergistic effect of adsorption and photo-Fenton reaction. Chem Eng J 379:122322. https://doi.org/10.1016/j.cej.2019.122322

28. Hou P, Shi C, Wu L, Hou X (2016) Chitosan/hydroxyapatite/ Fe3O4 magnetic composite for metal-complex dye AY220 removal: recyclable metal-promoted Fenton-like degradation. Microchem J 128:218-225. https://doi.org/10.1016/j.micro c.2016.04.022

29. Nasrellah H, Yassine I, Hatimi B, Joudi M, Chemaa A, El Gaini L, Hatim Z, El Mhammedi MA, Bakasse M (2017) New synthesis of hydroxyapatite from local phosphogypsum. J Mater Environ Sci 8:3168-3174

30. Jain SN et al (2020) Batch and continuous studies for adsorption of anionic dye onto waste tea residue: Kinetic, equilibrium, breakthrough and reusability studies. J Cleaner Prod 252:119778. https://doi.org/10.1016/j.jclepro.2019.119778

31. Pendekal MS, Tegginamat PK (2013) Hybrid drug delivery system for oropharyngeal, cervical and colorectal cancer-in vitro and in vivo evaluation. Saudi Pharm J 21(2):177-186. https://doi. org/10.1016/j.jsps.2012.07.002

32. Teng S-H, Lee E-J, Yoon B-H, Shin D-S, Kim H-E, Oh J-S (2009) Chitosan/nanohydroxyapatite composite membranes via dynamic filtration for guided bone regeneration. J Biomed Mater Res 88A(3):569-580. https://doi.org/10.1002/jbm.a.31897

33. Liu C, Ji X, Cheng G (2007) Template synthesis and characterization of highly ordered lamellar hydroxyapatite. Appl Surf Sci 253(16):6840-6843. https://doi.org/10.1016/j.apsus c.2007.01.119

34. Olad A, Farshi Azhar F (2014) The synergetic effect of bioactive ceramic and nanoclay on the properties of chitosan-gelatin/ nanohydroxyapatite-montmorillonite scaffold for bone tissue engineering. Ceram Int 40(7):10061-10072. https://doi. org/10.1016/j.ceramint.2014.04.010

35. Pawlak A, Mucha M (2003) Thermogravimetric and FTIR studies of chitosan blends. Thermochim Acta 396(1-2):153-166. https ://doi.org/10.1016/S0040-6031(02)00523-3

36. Katti KS, Katti DR, Dash R (2008) Synthesis and characterization of a novel chitosan/montmorillonite/hydroxyapatite nanocomposite for bone tissue engineering. Biomed Mater 3(3):034122. https://doi.org/10.1088/1748-6041/3/3/034122

37. Lawrie $\mathrm{G}$ et al (2007) Interactions between alginate and chitosan biopolymers characterized using FTIR and XPS. Biomacromol 8(8):2533-2541. https://doi.org/10.1021/bm070014y

38. SI Shanthi PM, Ashok M, Balasubramanian T, Riyasdeen A, Akbarsha MA (2009) Synthesis and characterization of nano-hydroxyapatite at ambient temperature using cationic surfactant. Mater Lett 63(24-25):2123-2125. https://doi. org/10.1016/j.matlet.2009.07.008

39. Sudheesh Kumar PT, Srinivasan S, Lakshmanan V-K, Tamura H, Nair SV, Jayakumar R (2011) $\beta$-Chitin hydrogel/nano hydroxyapatite composite scaffolds for tissue engineering applications. Carbohydr Polym 85(3):584-591. https://doi. org/10.1016/j.carbpol.2011.03.018

40. Silva DTC et al (2020) Adsorption of tamoxifen on montmorilIonite surface. Microporous Mesoporous Mater. https://doi. org/10.1016/j.micromeso.2020.110012

41. Marina Vargas Rodríguez $\mathrm{Y}$, Beltrán HI, Vázquez-Labastida $\mathrm{E}_{,}$ Linares-López C, Salmón M (2007) Synthesis and characterization of montmorillonite clays with modulable porosity induced with acids and superacids. J Mater Res 22(3):788-800. https:// doi.org/10.1557/jmr.2007.0098

42. Zhu H, Yang X, Mao Y, Chen Y, Long X, Yuan W (2011) Adsorption of EDTA on activated carbon from aqueous solutions. J Hazard Mater 185(2-3):951-957. https://doi.org/10.1016/j.jhazm at.2010.09.112

43. Ocholi OJ, Gimba CE, Ndukwe GI, Turoti M, Abechi SE, Edogbanya PR (2016) Effect of time on the adsorption of methylene blue methyl orange and indigo carmine onto activated carbon. IOSR 09(09):55-62. https://doi.org/10.9790/5736-0909015562

44. Rinaudo M, Pavlov G, Desbrières J (1999) Influence of acetic acid concentration on the solubilization of chitosan. Polymer 40(25):7029-7032. https://doi.org/10.1016/S0032 -3861(99)00056-7

45. Kang $S$ et al (2020) Enhanced removal of methyl orange on exfoliated montmorillonite/chitosan gel in presence of methylene blue. Chemosphere 238:124693. https://doi.org/10.1016/j. chemosphere.2019.124693

46. Sousa HR et al (2019) Evaluation of methylene blue removal by plasma activated palygorskites. J Mater Res Technol 8(6):54325442. https://doi.org/10.1016/j.jmrt.2019.09.011

47. Obeid L et al (2013) Chitosan/maghemite composite: a magsorbent for the adsorption of methyl orange. J Colloid Interface Sci 410:52-58. https://doi.org/10.1016/j.jcis.2013.07.057

48. Chiou M-S, Li H-Y (2002) Equilibrium and kinetic modeling of adsorption of reactive dye on cross-linked chitosan beads. $J$ Hazard Mater 93(2):233-248. https://doi.org/10.1016/S0304 -3894(02), 00030-4

49. Yao $Y$, Bing $H$, Feifei $X$, Xiaofeng $C$ (2011) Equilibrium and kinetic studies of methyl orange adsorption on multiwalled carbon nanotubes. Chem Eng J 170(1):82-89. https://doi.org/10.1016/j. cej.2011.03.031

50. Wong $S$ et al (2019) Adsorption of anionic dyes on spent tea leaves modified with polyethyleneimine (PEI-STL). J Cleaner Prod 206:394-406. https://doi.org/10.1016/j.jclepro.2018.09.201

51. Chen S, Zhang J, Zhang C, Yue Q, Li Y, Li C (2010) Equilibrium and kinetic studies of methyl orange and methyl violet adsorption on activated carbon derived from Phragmites australis. Desalination 252(1-3):149-156. https://doi.org/10.1016/j.desal .2009.10.010

52. Annadurai G, Juang R-S, Lee D-J (2002) Use of cellulosebased wastes for adsorption of dyes from aqueous solutions. J Hazard Mater 92(3):263-274. https://doi.org/10.1016/S0304 -3894(02)00017-1

53. Ho YS, McKay G (1999) Pseudo-second order model for sorption processes. Process Bioche 34(5):451-465. https://doi. org/10.1016/S0032-9592(98)00112-5

54. Paşka OM, Păcurariu C, Muntean SG (2014) Kinetic and thermodynamic studies on methylene blue biosorption using cornhusk. RSC Adv 4(107):62621-62630. https://doi.org/10.1039/ C4RA10504D

55. Arami M, Limaee N, Mahmoodi N, Tabrizi N (2006) Equilibrium and kinetics studies for the adsorption of direct and acid dyes from aqueous solution by soy meal hull. J Hazard Mater 135(13):171-179. https://doi.org/10.1016/j.jhazmat.2005.11.044

56. Muntean SG, Todea A, Rădulescu-Grad ME, Popa A (2014) Decontamination of colored wastewater using synthetic sorbents. 
Pure Appl Chem 86(11):1771-1780. https://doi.org/10.1515/ pac-2014-0805

57. Langmuir I (1918) The adsorption of gases on plane surfaces of glass, mica and platinum. J Am Chem Soc. https://doi. org/10.1021/ja02242a004

58. Vimonses V, Lei S, Jin B, Chow CWK, Saint C (2009) Kinetic study and equilibrium isotherm analysis of Congo Red adsorption by clay materials. Chem Eng J 148(2-3):354-364. https://doi. org/10.1016/j.cej.2008.09.009

59. Günay A, Arslankaya E, Tosun I (2007) Lead removal from aqueous solution by natural and pretreated clinoptilolite: adsorption equilibrium and kinetics. J Hazard Mater 146(1-2):362-371. https://doi.org/10.1016/j.jhazmat.2006.12.034

60. Meng B, GuoXiaoping Q, RenWenlong M, Shen J (2020) Modified bentonite by polyhedral oligomeric silsesquioxane and quaternary ammonium salt and adsorption characteristics for dye. $J$ Saudi Chem Soc 24(3):334-344

61. Venkatesha TG, Viswanatha R, Arthoba Nayaka Y, Chethana BK (2012) Kinetics and thermodynamics of reactive and vat dyes adsorption on MgO nanoparticles. Chem Eng J 198-199:1-10. https://doi.org/10.1016/j.cej.2012.05.071

62. Ren Y, Abbood HA, He F, Peng H, Huang K (2013) Magnetic EDTAmodified chitosan/SiO2/Fe3O4 adsorbent: preparation, characterization, and application in heavy metal adsorption. Chem Eng J 226:300-311. https://doi.org/10.1016/j.cej.2013.04.059

63. Lima EC, Hosseini-Bandegharaei A, Moreno-Piraján JC, Anastopoulos I (2019) A critical review of the estimation of the thermodynamic parameters on adsorption equilibria Wrong use of equilibrium constant in the Van't Hoof equation for calculation of thermodynamic parameters of adsorption. J Mol Liq 273:425434. https://doi.org/10.1016/j.molliq.2018.10.048

64. Akperov EO, Akperov OH (2019) The wastage of the cotton stalks (Gossypium hirsutum L.) as low-cost adsorbent for removal of the Basic Green 5 dye from aqueous solutions. Appl Water Sci 9(8):183. https://doi.org/10.1007/s13201-019-1071-0

65. Hafdi H et al (2020) Design of a new low cost natural phosphate doped by nickel oxide nanoparticles for capacitive adsorption of reactive red 141 azo dye. Environ Res 184:109322. https://doi. org/10.1016/j.envres.2020.109322

66. Jiang R, Fu Y-Q, Zhu H-Y, Yao J, Xiao L (2012) Removal of methyl orange from aqueous solutions by magnetic maghemite/chitosan nanocomposite films: Adsorption kinetics and equilibrium. J Appl Polym Sci 125(S2):E540-E549. https ://doi.org/10.1002/app.37003

67. Zhang L, Hu P, Wang J, Huang R (2016) Crosslinked quaternized chitosan/bentonite composite for the removal of Amino. black 10B from aqueous solutions. Int J Biol Macromol 93:217-225. https://doi.org/10.1016/j.ijbiomac.2016.08.018

68. Prado AGS, Torres JD, Faria EA, Dias SCL (2004) Comparative adsorption studies of indigo carmine dye on chitin and chitosan. J Colloid Interface Sci 277(1):43-47. https://doi.org/10.1016/j. jcis.2004.04.056

69. Fatombi JK et al (2019) Adsorption of indigo carmine from aqueous solution by chitosan and chitosan/activated carbon composite: kinetics isotherms and thermodynamics studies. Fibers Polym 20(9):1820-1832. https://doi.org/10.1007/s1222 1-019-1107-y

70. Allouche F-N, Yassaa N, Lounici H (2015) Sorption of methyl orange from aqueous solution on chitosan biomass. Proc Earth Planet Sci 15:596-601. https://doi.org/10.1016/j.proep s.2015.08.109

71. Fan L, Luo C, Li X, Lu F, Qiu H, Sun M (2012) Fabrication of novel magnetic chitosan grafted with graphene oxide to enhance adsorption properties for methyl blue. J Hazard Mater 215216:272-279. https://doi.org/10.1016/j.jhazmat.2012.02.068

72. Wang W, Zhao Y, Bai H, Zhang T, Ibarra-Galvan V, Song S (2018) Methylene blue removal from water using the hydrogel beads of poly(vinyl alcohol)-sodium alginate-chitosan-montmorillonite. Carbohydr Polym 198:518-528. https://doi.org/10.1016/j.carbp ol.2018.06.124

73. Kang $S$ et al (2018) Removal of methylene blue from water with montmorillonite nanosheets/chitosan hydrogels as adsorbent. Appl Surf Sci 448:203-211. https://doi.org/10.1016/j.apsus c.2018.04.037

Publisher's Note Springer Nature remains neutral with regard to jurisdictional claims in published maps and institutional affiliations. 